\title{
Physico-chemical Analysis of Surface and Ground Water in Selected Sites of Dehradun, Uttarakhand, India
}

Rajdeo Kumar ${ }^{1 *}$, Ashish Chauhan ${ }^{2}$ and Laxmi Rawat ${ }^{1}$

${ }^{1}$ Ecology, Climate Change and Forest Influence Division, Forest Research Institute, Dehradun, Uttarakhand, India

${ }^{2}$ National Institute of Pharmaceutical Education and Research, Mohali, Punjab, India

\begin{abstract}
Hydrochemical study of surface and ground water were performed for determining its suitability for drinking, industrial and agricultural purposes. In this study, the evaluation of various physico-chemical parameters such as $\mathrm{pH}$, $\mathrm{EC}$, TDS, bicarbonate and alkali metals ( $\mathrm{Na}, \mathrm{K}, \mathrm{Ca}$ and $\mathrm{Mg}$ ) of the surface and ground water has been carried out in selected sites of Dehradun using advanced analytical techniques. All results were compared with the standard limits as per WHO guidelines for drinking water and were accessed stastitiscally. The deterioraton in the quality of the water could be accounted to rapid urbo-industralization activities, increase in population with change of life style, excess use of chemical fertilizers, pesticides in soil to meet the increasing demand in the market, destroyed the water quality of ecologically rich state of Uttarakhand, India.
\end{abstract}

Keywords: Industrialization; Surface water; Ground water; Physicochemical; Pollution; Alkali metals; Population; Soils; Pesticide; Fertilizer

\section{Introduction}

Water is one of the most important natural resources and a prerequisite for sustainance of life. It is a key element for the socioeconomic development of a country. Agriculture is a major source of water demand in an agrarian country like India. Exploitation of water resources to meet the demand of agricultural products with the exponential population growth and equally supported by industrialization and urbanization put ground water resources under great threat both in terms of quality as well as quantity. The groundwater quality in any area is a function of its physical and chemical parameters which in turn are highly influenced by geological formations, climatic conditions and anthropogenic activities [1].

Water pollution is a global threat that varies in magnitude and type from one region to another. Water pollutants has been classified into eight categories; sewage, disease causing agents, sediment pollution, inorganic plant and algal nutrients, organic compounds, inorganic chemicals, radioactive substances and thermal pollution. Rapid industrialization plays an important role in polluting the environment and causes severe degradation in pedosphere, hydrosphere and atmosphere. Water used in industries creates a waste that has potential hazard for our environment because of the introduction of various contaminants such as heavy metals into soil and water resources $[2,3]$.

Rapid industrialization and flow of urban population in past few years is suspected to deteriorate the water quality of the ecologically rich Himalayan State of India namely Uttarakhand. There have been several studies on water quality monitoring of rivers flowing through Uttarakhand [4-7]. Effluents from pharmaceuticals or chemical industries contribute to water pollution. Industrial Effluents usually contains specific and readily identifiable chemical compounds. In India, most of the large scale industries have effluent treatment plant facilities but a number of small and medium sized industries do not have adequate effluent treatment facilities. Such industries cannot afford enormous investments in pollution control equipment as their profit margin is negligible [8].

It is also reported that uncontrolled use of pesticides and fertilizers to increase the agriculture production to meet the increasing demand has devastating impact on water quality. The change in land use or land cover pattern in an area is also being considered to have a strong impact on the ground water quality $[9,10]$. Therefore, assessment of groundwater quality is needed to ensure safer use of it. Surface water resources are rapidly shrinking due to the excessive use and changes in the monsoon pattern in the Dehradun region, that causes a tremendous amount of pressure on ground water resources [11-13].

The rapid urbanization, industrialization, intensive agriculture and growing demand has adversely affected the physio-chemical parameters of ground and surface water. The groundwater level is declining continuously and thus increasing the dependence of people on surface water resources. Therefore analysis of river water quality is very essential for sustainable use of river water resources. The river water quality in a region is largely determined by the natural processes viz., precipitation rate, weathering processes, soil erosion etc. as well as anthropogenic processes i.e., urban, industrial, agricultural activities and increasing exploitation of water resources $[10,14]$. The municipal and industrial waste water discharge (point as well as non-point sources of pollution) constitutes the constant polluting source of river water quality. The surface run-off during the rainy season also affects river water quality. Seasonal variations in precipitation, surface runoff, ground water flow, interception and abstraction of river water have marked effect on concentration of river water pollutants. The hydrogeochemistry of river water is controlled by a series of factors such as climate, vegetation, topography and geology of the catchment area. The river water ecosystem is affected by fluctuations in physical and chemical characteristic of river $[15,16]$.

${ }^{*}$ Corresponding author: Rajdeo Kumar, Ecology, Climate Change and Forest Influence Division, Forest Research Institute, Dehradun, Uttarakhand, India, Tel: +919464616773; E-mail: rajdeo.kumar@gmail.com

Received December 02, 2016; Accepted December 10, 2016; Published January 02,2017

Citation: Kumar R, Chauhan A, Rawat L (2017) Physico-chemical Analysis of Surface and Ground Water in Selected Sites of Dehradun, Uttarakhand, India. J Environ Anal Toxicol 6: 420. doi: 10.4172/2161-0525.1000420

Copyright: () 2017 Kumar R, et al. This is an open-access article distributed under the terms of the Creative Commons Attribution License, which permits unrestricted use, distribution, and reproduction in any medium, provided the original author and source are credited. 
Citation: Kumar R, Chauhan A, Rawat L (2017) Physico-chemical Analysis of Surface and Ground Water in Selected Sites of Dehradun, Uttarakhand, India. J Environ Anal Toxicol 6: 420. doi: 10.4172/2161-0525.1000420

Page 2 of 6

\section{Study area}

Dehradun is the capital city of Uttarakhand state, which came into existence on $9^{\text {th }}$ of November 2000. It is situated towards north of India's capital city, New Delhi and at a distance of about $236 \mathrm{~km}$ by road. Dehradun is in the Doon valley on the foothills of the Himalayas nestled between two of India's mightiest rivers- the Ganges on the east and the Yamuna on the west. The city is famous for its picturesque landscape and slightly milder climate and provides a gateway to the surrounding region.

\section{Location and geographical area}

Dehradun is popular for Himalayan tourist destinations such as Mussoorie, Nainital, Auli and the holy Hindu cities of Haridwar and Rishikesh along with the pilgrimage to Char Dham of Gangotri, Jamunotri, Badrith and Kedarnath along with Hemkund Saheb.

Dehradun district has various types of physical features, from the Himalayan mountains to plains. Raiwala is the lowest point with altitude $315 \mathrm{~m}$ and the highest point is in the Tyuni hills, rising to $3700 \mathrm{~m}$. This district is divided into two major parts, Shivalik Himalayas and Jaunsar Bavar, which is located in the foothills of Himalayas. In the north, district of Uttarkashi, east by Tehri and Pauri, west by Sirmaur district of Himachal Pradesh with Tons and Yamuna rivers and south, by Haridwar and Saharanpur district of Uttar Pradesh is situated.

Doon valley is a saucer shaped, intermountain boulder valley with coarse clastic fan i.e., Doon gravel of late Pleistocene and Holocene. Lying between latitudes $29^{\circ} 55^{\prime} \mathrm{N}$ and $30^{\circ} 30^{\prime} \mathrm{N}$ and longitudes $77^{\circ} 35^{\prime} \mathrm{E}$ and $78^{\circ} 24^{\prime} \mathrm{E}$ shown in Figure 1 and covering an area of approximately $150 \mathrm{~km}$; about $20 \mathrm{~km}$ wide and $80 \mathrm{~km}$ long. Doon valley slopes towards both South-East and South-West. It is a watershed bounded on the two sides by the river Ganga and the Yamuna, Ganga in the South-East and Yamuna in the North-West, covering an approximate area of $210 \mathrm{~km}^{2}$. It is bounded by the lesser Himalayas, which rises to about $2500 \mathrm{~m}$ to the North-East, Shiwalik hills having maximum height of $1400 \mathrm{~m}$ to the South-West.

\section{Climate}

The climate of the Dehradun is generally temperate type. It varies greatly from tropical to severe cold depending upon the altitude of the area. The temperature drops below freezing point not only at high altitude but even at places like Dehradun, when the higher peaks are under the snow. The area receives an average annual rainfall of approximately $2000 \mathrm{~mm}$. Most of the annual rainfall in the district is received during the monsoon months of June to September, July and August being the rainiest months.

\section{Forest}

Dehradun is surrounded by very dense forest which is chiefly

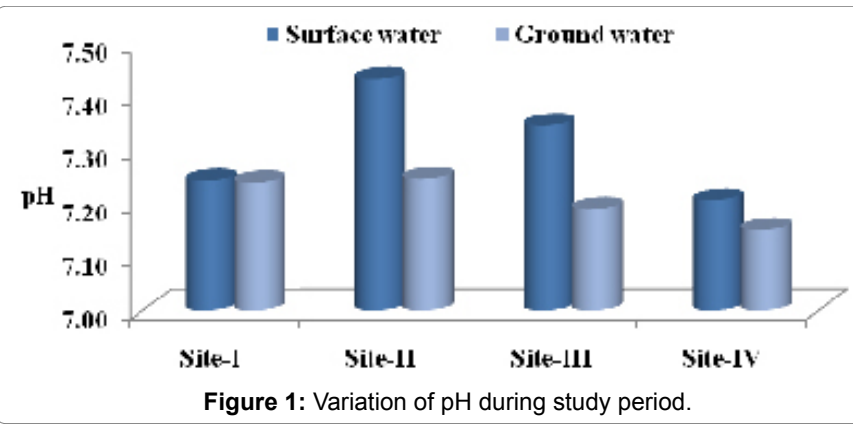

stocked with Sal (Shorea robusta) trees. Its products are used as fuel, fodder and medicinal herbs, they also yield a variety of products like honey, lakh, gum, resin, catechu, wax, horns and hides. Sal is the main timber species and is generally pure towards the Siwalik ridges, a mixture of miscellaneous species is found in the lower parts. Sal forest and coniferous forests are predominant in the western part of tehsil Dehradun. Sal is the predominant species mixed with other associates viz., Mallotus philippensis, Michelia champaca, Syzygium cumini, Cinnamomum camphora, Flacourtia ramontchi, etc.

\section{Materials and Methods}

Four experimental sites were selected from the present study to analyse water samples for various physico-chemical along with alkali metals analysis of surface and ground water.

\section{FRI campus as Site-I}

New forest estate lies north of Dehradun- Chakrata Road, about 6 $\mathrm{Km}$ from main Dehradun town surrounding Clock Tower. The area is situated between $30^{\circ} 20^{\prime} 05.4^{\prime \prime} \mathrm{N}$ Latitude and $77^{\circ} 59^{\prime} 15.3^{\prime \prime} \mathrm{E}$ longitude and $640.08 \mathrm{~m}$.

\section{Clock tower as Site-II}

The clock tower is the heart of Dehradun city and encircled by the city's commercial centres like famous "Paltan bazar" with its old traditional shops, some old cinema halls like "Kanak, Chhayadeep" etc. The area is situated between latitude $30^{\circ} 19^{\prime} 32.4^{\prime \prime} \mathrm{N}$ and longitude $78^{\circ} 02^{\prime} 34.4^{\prime \prime} \mathrm{E}$ and is located at an elevation of $640 \mathrm{~m}$.

\section{Selaqui industrial area as Site-III}

Selaqui is located towards west of the main township of Dehradun along the Chakrata road and it is about $19 \mathrm{~km}$ from the Clock tower. The area is situated between latitude $30^{\circ} 21^{\prime} 40^{\prime \prime} \mathrm{N}$ and longitude $77^{\circ} 50^{\prime} 44.8^{\prime \prime} \mathrm{E}$ at an altitude of $635 \mathrm{~m}$.

\section{Karwapani as Site-IV}

There are a number of wetlands in the Doon valley, the most common are fresh water swamps include Doodpani, Golatappar, Gularghati, Laltappar, Manuswamp, Mothoranwala, Nakranda, Ramgrah and Karwapani. It lies in the latitude $30^{\circ} 2^{\prime \prime}$ to $30^{\circ} 26^{\prime \prime}(\mathrm{N})$ and Longitude $77^{\circ} 52^{\prime \prime}$ to $78^{\circ}-19^{\prime \prime}$ (E) [17].

Surface and ground water samples were collected in a cleaned polyethylene bottles from all four study sites for the various physiochemical analysis. $200 \mathrm{ml}$ of each water sample was digested with $5 \mathrm{ml}$ of conc. Nitric acid : Perchloric acid (in a ratio 9:4) and the mixture was kept on a hot plate. The clear solutions were filtered through Whatman no. 42 filter paper and diluted to $50 \mathrm{ml}$ for analysis by AAS (Atomic Absorbtion Spectrophotometer). Finally the samples were stored at $4^{\circ} \mathrm{C}$ to minimize chemical alterations.

\section{Analytical techniques}

$\mathrm{pH}$ was determined by $\mathrm{pH}$ Tutor (Eutech instrument). Electrical conductivity (EC) was determined by Systronics (Model no. Conductivity meter 306) measured in micro-Siemens $/ \mathrm{cm}$. Total Dissolved Solid (TDS) was measured by gravimetric method and $\mathrm{HCO}_{3}^{-}$was analysed by titration method. Alkali metals were determined by the using of Flame photometer (Microprocessor flame photometer, Model No. 1381). AAS (Lab India, Model no AA7000), was used for detection of magnesium ions. The results obtained are the mean of three readings. 
Citation: Kumar R, Chauhan A, Rawat L (2017) Physico-chemical Analysis of Surface and Ground Water in Selected Sites of Dehradun, Uttarakhand, India. J Environ Anal Toxicol 6: 420. doi: 10.4172/2161-0525.1000420

\section{Statistical analysis}

All data generated through analysis of water was analyzed statistically using GenSTAT software for two way ANOVA. Significance among sites, seasons and among sites and seasons together was tested at 0.05 level.

\section{Results and Discussion}

Water samples (both surface and ground water) of all four experimental sites were analyzed for various physico-chemical parameters viz. $\mathrm{pH}, \mathrm{EC}$, TDS, bicarbonate $\left(\mathrm{HCO}_{3}^{-}\right)$, alkali metals such as sodium $(\mathrm{Na})$, potassium $(\mathrm{K})$, calcium $(\mathrm{Ca})$ and magnesium $(\mathrm{Mg})$ at all four study sites, which are described in following paragraphs as can be seen in Table 1.

\section{pH}

After observation of $\mathrm{pH}$ in surface water at site-II, had highest $\mathrm{pH}$ (7.43) among all the study sites and the lowest $\mathrm{pH}$ (7.21) was found at site-IV. However, in case of ground water, the highest $\mathrm{pH}$ (7.25) was also found at site-II and lowest (7.15) at site-IV (Figure 1). In the present investigation $\mathrm{pH}$ was found to be in the range of 7.21 to 7.45 and 7.15 to 7.25 in surface and ground water, respectively which is low as compared to standard limit.

The ANOVA results showed that there was no significant difference among sites, in surface water. Similarly, in ground water also; there was no significant difference among sites.

Low $\mathrm{pH}$ of surface water of various rivers and other water sources may be due to dilution effect of rain water during rainy season, as reported by various workers. $\mathrm{pH}$ controls the chemical state of many nutrients including dissolved oxygen, phosphate, nitrate etc. due to this effect, aquatic organisms are affected by $\mathrm{pH}$ changes as their metabolic activities are $\mathrm{pH}$ dependent. Nonetheless, the $\mathrm{pH}$ has no direct adverse effects on health; however, higher values of $\mathrm{pH}$ hasten the scale formation in water heating apparatus and also reduce germicidal potential of chloride results in the formation of trihalomethanes, which are toxic in nature [17-19].

\section{$\mathrm{EC}\left(\mu \mathrm{S} \mathrm{cm} \mathrm{cm}^{-1}\right)$}

Electrical Conductivity (EC) in surface and ground water were varied among all four sites (Figure 2) and it was recorded that highest EC $\left(502.96 \mu \mathrm{Scm}^{-1}\right)$ was at site-II and lowest was at site-IV $(362.05$ $\left.\mu \mathrm{Scm}^{-1}\right)$ in surface water. However, in case of ground water, EC was recorded highest at site-I $\left(359.23 \mu \mathrm{Scm}^{-1}\right)$ and lowest was at site-II $\left(346.26 \mu \mathrm{Scm}^{-1}\right)$.

EC was found in the range of 362.05 to 502.96 and 346.26 to 359.23 in surface and ground water, respectively which is high as compared to standard limit. It may be occurred due to pollution load by anthropogenic activity.

The ANOVA results showed that there was significant difference at $0.05 \%$ level among sites in surface water. However, in ground water, results showed that there was no significant difference among sites.

Electrical conductivity (EC) is a measure of the ability of water to conduct electrical current. This is measured in terms of the amount of ions in a solution. The more the ions in the solution the higher is the conductivity. Based on the fact that seawater has higher conductivity in comparison to fresh water. Thus, it could be concluded that conductivity in water is affected by the presence of inorganic dissolved solids such as chloride, nitrate, sulfate and phosphate anions or sodium, magnesium, calcium, iron and aluminum cations. Various phenomenon are reported in the literature which causes enhancement in the value of EC such as natural enrichment in electrolytes, phenomena of mineralization or weathering of sediments [20].

These have tendency to enrich levels of conducting species such as sulphate, chloride, phosphate and heavy metals present in the effluent Present results are in line with the previous findings reported in the literature $[21,22]$.

\section{TDS ( $\left.\mathrm{mgl}^{-1}\right)$}

TDS was analyzed in surface and ground water among all four study sites. TDS was recorded highest at site-III $\left(673.33 \mathrm{mgl}^{-1}\right)$ while lowest was found at site-I $\left(496.11 \mathrm{mgl}^{-1}\right)$ in case of surface water (Figure 3) but in ground water, TDS was highest at site-III $\left(465.55 \mathrm{mgl}^{-1}\right)$ and lowest at site-I $\left(389.11 \mathrm{mgl}^{-1}\right)$.

TDS was found in the range of 496.11 to $673.33 \mathrm{mgl}^{-1}$ and 389.11 to $465.55 \mathrm{mgl}^{-1}$ in surface and ground water, respectively which is high in surface water as compared to standard limit and in case of ground water, it was found below the standard limit.

The ANOVA results exhibited that there was highly significant (at $0.05 \%$ level) difference among the sites in surface water. However, in ground water, there was significant difference at $0.05 \%$ level among sites.

According to WHO and USPH, total dissolved solid values for drinking water $<500 \mathrm{mgl}^{-1}$ minimum is the desirable limit and 1500 $\mathrm{mgl}^{-1}$ as maximum permissible limit (ICMR). The excess of dissolved solids create an imbalance due to increased turbidity and cause suffocation to aquatic life even in the presence of high dissolved Oxygen. Water with high residue is normally less palatable and may induce an unfavourable physiological reaction in the transient consumer and even may cause gastrointestinal irritation. Moreover, water containing high solid concentration may cause constipation

\begin{tabular}{|c|c|c|c|c|c|c|c|c|c|c|c|}
\hline \multirow{2}{*}{ S. No. } & \multirow{2}{*}{ Parameter } & \multirow{2}{*}{ WHO } & \multirow{2}{*}{$\begin{array}{l}\text { Indian } \\
\text { standard }\end{array}$} & \multicolumn{4}{|c|}{ Surface water } & \multicolumn{4}{|c|}{ Ground water } \\
\hline & & & & Site-I & Site-II & Site-III & Site-IV & Site-I & Site-II & Site-III & Site-IV \\
\hline 1. & $\mathrm{pH}$ & $6.5-9.2$ & $6.5-9.5$ & 7.24 & 7.43 & 7.35 & 7.21 & 7.24 & 7.25 & 7.19 & 7.15 \\
\hline 2. & $\mathrm{EC}(\mu \mathrm{mho} / \mathrm{cm})$ & 300 & - & 389.67 & 502.96 & 405.45 & 362.05 & 359.23 & 346.26 & 356.19 & 347.75 \\
\hline 3. & TDS $\left(\mathrm{mgl}^{-1}\right)$ & 500 & & 496.11 & 663.33 & 673.33 & 651.11 & 389.11 & 398.89 & 465.55 & 404.44 \\
\hline 4. & Total Alkalinity $\left(\mathrm{mgl}^{-1}\right)$ & - & $200\left(\mathrm{mgl}^{-1}\right)$ & 165.00 & 172.62 & 161.45 & 154.45 & 158.66 & 159.61 & 150.37 & 147.44 \\
\hline 5. & Sodium $\left(\mathrm{mgl}^{-1}\right)$ & 200 & $180\left(\mathrm{mgl}^{-1}\right)$ & 7.90 & 11.00 & 10.02 & 5.81 & 5.73 & 6.19 & 5.63 & 5.71 \\
\hline 6. & Potassium $\left(\mathrm{mgl}^{-1}\right)$ & 12 & & 4.52 & 15.29 & 6.53 & 5.37 & 2.96 & 7.09 & 4.67 & 4.07 \\
\hline 7. & Calcium $\left(\mathrm{mgl}^{-1}\right)$ & 75 & & 35.43 & 35.87 & 36.96 & 30.64 & 23.58 & 30.61 & 28.67 & 20.93 \\
\hline 8. & Magnesium (mgl-1) & 50 & & 22.09 & 24.42 & 26.87 & 18.16 & 18.97 & 21.18 & 18.60 & 17.25 \\
\hline
\end{tabular}

where, $\mu \mathrm{mho} / \mathrm{cm}$ or $\mu \mathrm{Scm}^{-1}$ refers to unit of electrical conductivity

Table 1: Comparison of surface and ground water quality with drinking water standards (WHO and Indian Standard). 
Citation: Kumar R, Chauhan A, Rawat L (2017) Physico-chemical Analysis of Surface and Ground Water in Selected Sites of Dehradun, Uttarakhand, India. J Environ Anal Toxicol 6: 420. doi: 10.4172/2161-0525.1000420

Page 4 of 6

effects. Thus, high level of TDS may aesthetically be unsatisfactory for bathing and washing $[23,24]$.

\section{$\mathrm{HCO}_{3}^{-}\left(\mathrm{mgl}^{-1}\right)$}

$\mathrm{HCO}_{3}{ }^{-}$was analyzed in surface and ground water at all four selected sites. The highest $\mathrm{HCO}_{3}^{-}$was recorded in surface water (Figure 4) at site-II (172.62 mgl-1) and lowest at site-IV (154.45 mgl-1). However, in case of ground water, the highest value was observed at site-II (159.61 $\left.\mathrm{mgl}^{-1}\right)$ and lowest was at site-IV $\left(147.44 \mathrm{mgl}^{-1}\right)$. Bicarbonate was found in between 154.45 to $172.62 \mathrm{mgl}^{-1}$ and 147.44 to $159.61 \mathrm{mgl}^{-1}$ in surface and ground water, respectively which is low as compared to standard limit.

ANOVA findings suggested that the $\mathrm{HCO}_{3}{ }^{-}$differed significantly at $0.05 \%$ level among sites in surface water, while in case of ground water, results displayed that there was also significant difference at $0.05 \%$ level in among sites.

The primary source of carbonate and bicarbonate ions in surface water and ground water is dissolved carbon dioxide derived from the rain water. As it enters the soil or rocks, it dissolves more carbon dioxide in water. The desirable limit and permissible limit of bicarbonate in water is $200 \mathrm{mgl}^{-1}$ to $600 \mathrm{mgl}^{-1}$. Alkalinity of water is defined as the ionic concentration which can neutralize the hydrogen ions. The phenolphthalein alkalinity value is zero indicating absence of any carbonate and hydroxyl ions. The bicarbonate alkalinity is expressed as

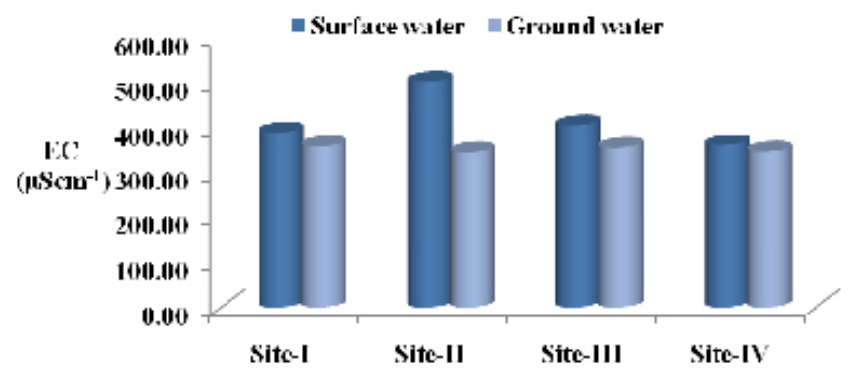

Figure 2: Variation of EC during study period.

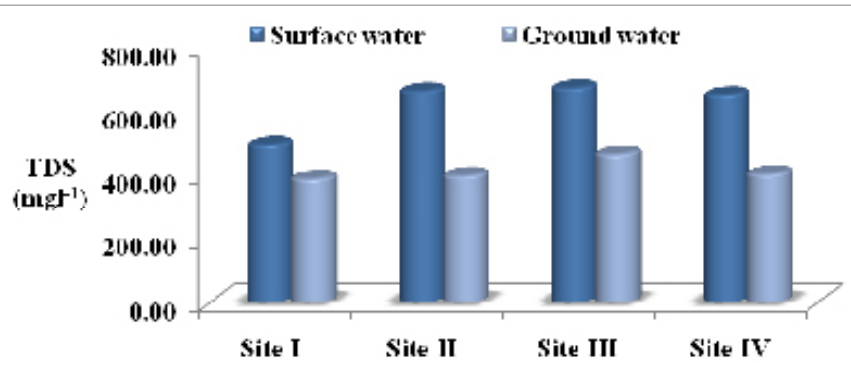

Figure 3: Variation of TDS during study period.

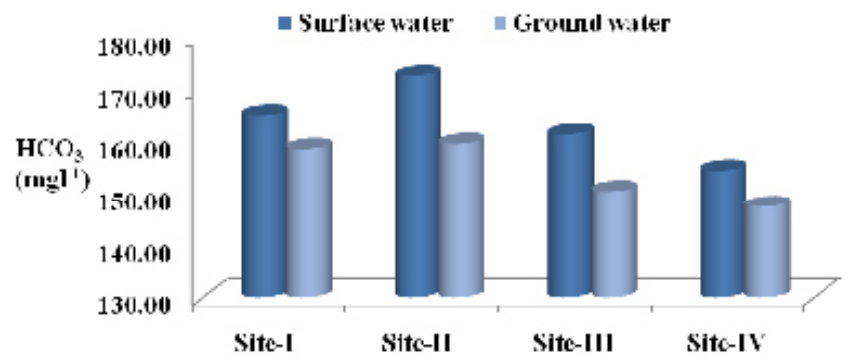

Figure 4: Variation of $\mathrm{HCO}_{3}^{-}$during study period. a total alkalinity which ranges between $218-460 \mathrm{mgl}^{-1}$. The alkalinity values of all samples of present study are within the permissible limit of $600 \mathrm{ppm}$ or $\mathrm{mgl}^{-1}$ [25].

\section{Sodium $\left(\mathrm{mgl}^{-1}\right)$}

Sodium $(\mathrm{Na})$ was analyzed in surface and ground water at all four selected sites and the highest sodium concentration was recorded (Figure 5) in surface water at site-II $\left(10.00 \mathrm{mgl}^{-1}\right)$ and lowest at site-IV $\left(5.81 \mathrm{mgl}^{-1}\right)$. However, in case of ground water, the highest concentration was observed at site-II $\left(6.19 \mathrm{mgl}^{-1}\right)$ and lowest was at site-III $(5.63 \mathrm{mgl}$ $\left.{ }^{1}\right)$. Sodium was found in range of 5.81 to 11.00 and 5.63 to $6.19 \mathrm{mgl}^{-1}$ in surface and ground water, respectively which is low as compared to standard limit.

The ANOVA results suggested that there was highly significant (at $0.05 \%$ level) difference among the sites, in both surface and ground water of all samples.

Sodium plays an important role in preventing many fatal diseases like kidney damages, hypertension, headache, etc. in human body. According to WHO report, in most of countries, majority of water supply bears less than $20 \mathrm{mgl}^{-1}$ while in some countries the sodium quantity in water exceeded from $250 \mathrm{mgl}^{-1}$. WHO defines the concentration of sodium in drinking water up to $200 \mathrm{mgl}^{-1}$. Ground water with high $\mathrm{Na}$ content is not suitable for agricultural usage as it tends to deteriorate soil quality [26].

\section{Potassium $\left(\mathrm{mgl}^{-1}\right)$}

Similarly, potassium (K) was analyzed in surface and ground water among all four selected sites and the highest potassium concentration was observed in surface water (Figure 6) at site-II $\left(15.29 \mathrm{mgl}^{-1}\right)$ and lowest at site-I $\left(4.52 \mathrm{mgl}^{-1}\right)$. However, in case of ground water, the highest concentration was found at site-II $\left(7.09 \mathrm{mgl}^{-1}\right)$ and lowest was at site-I $\left(2.96 \mathrm{mgl}^{-1}\right)$.

$\mathrm{K}$ was found in between 4.52 to 15.29 and 2.96 to $7.09 \mathrm{mgl}^{-1}$ in surface and ground water, respectively which is low in ground water as

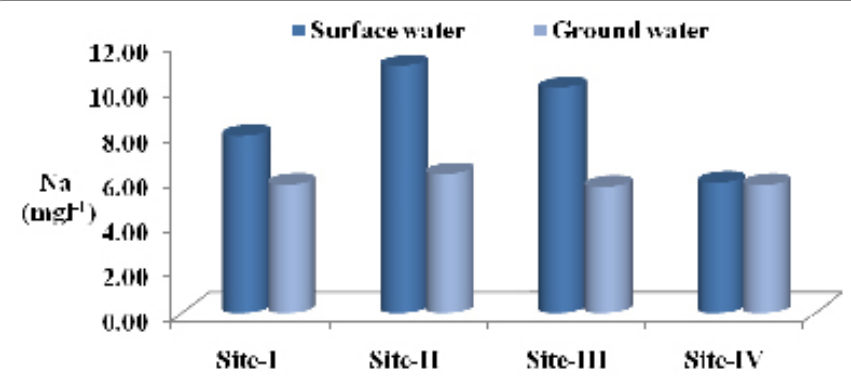

Figure 5: Variation of Na during study period.

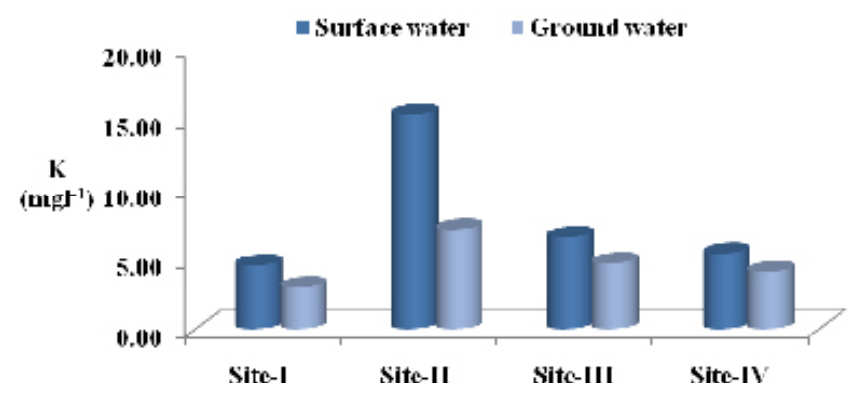

Figure 6: Variation of potassium (K) during study period 
Citation: Kumar R, Chauhan A, Rawat L (2017) Physico-chemical Analysis of Surface and Ground Water in Selected Sites of Dehradun, Uttarakhand, India. J Environ Anal Toxicol 6: 420. doi: 10.4172/2161-0525.1000420

compared to standard limit but high at site-II of surface water because of urbanisation.

The ANOVA results displayed that there was highly significant difference at $0.05 \%$ level among the sites, in both surface and ground water of all samples.

According to WHO and European Economic Community (EEC, 1980) have prescribed the guideline level of potassium at $12 \mathrm{mgl}^{-1}$ and 10 $\mathrm{mgl}^{-1}$ in drinking water, respectively. Though potassium is extensively found in some of igneous and sedimentary rocks, its concentration in natural waters is usually quite low. This is due to the fact that potassium minerals offer resistance to weathering and dissolution [27].

The total potassium concentration in human body lies between 110 to $140 \mathrm{~g}$. It is vital for human body functions like heart protection, regulation of blood pressure, protein dissolution, muscle weakness, heart rhythm disorder etc.

\section{Calcium $\left(\mathrm{mgl}^{-1}\right)$}

Calcium (Ca) was analyzed in surface and ground water at all four sites in which, the highest calcium concentration was observed in surface water (Figure 7) at site-III $\left(36.96 \mathrm{mgl}^{-1}\right)$ and lowest was at site-I $\left(35.43 \mathrm{mgl}^{-1}\right)$. However, in ground water, the highest concentration was recorded at site-II $\left(30.61 \mathrm{mgl}^{-1}\right)$ and lowest was at site-IV $\left(20.93 \mathrm{mgl}^{-1}\right)$.

Ca was found to be in the range of 30.64 to 36.96 and 20.93 to $30.61 \mathrm{mgl}^{-1}$ in surface and ground water, respectively which is low as compared to standard limit.

The ANOVA results revealed that there was highly significant difference (at $0.05 \%$ level) among the sites in surface water and in ground water both of all samples.

Calcium (Ca) is fifth most abundant element in the earth crust and is very important for human cell physiology and bones. About $95 \%$ calcium in human body stored in bones and teeth. The high deficiency of calcium in humans may cause rickets, poor blood clotting, bone fracture etc. and the exceeding limit of calcium produced cardiovascular diseases. According to WHO and ISI standards its permissible range in drinking water is $75 \mathrm{mgl}^{-1}$, whereas PSQCA established the limit of 200 $\mathrm{mgl}^{-1}[28-30]$.

\section{Magnesium $\left(\mathrm{mgl}^{-1}\right)$}

Magnesium $(\mathrm{Mg})$ was analyzed in surface and ground water at all four selected sites. The highest magnesium concentration was observed in surface water (Figure 8 ) at site-III $\left(26.87 \mathrm{mgl}^{-1}\right.$ ) and lowest was at site-IV $\left(18.16 \mathrm{mgl}^{-1}\right)$. However, in ground water, the highest concentration was recorded at site-II $\left(21.18 \mathrm{mgl}^{-1}\right)$ and lowest was at site-IV $\left(17.25 \mathrm{mgl}^{-1}\right)$.

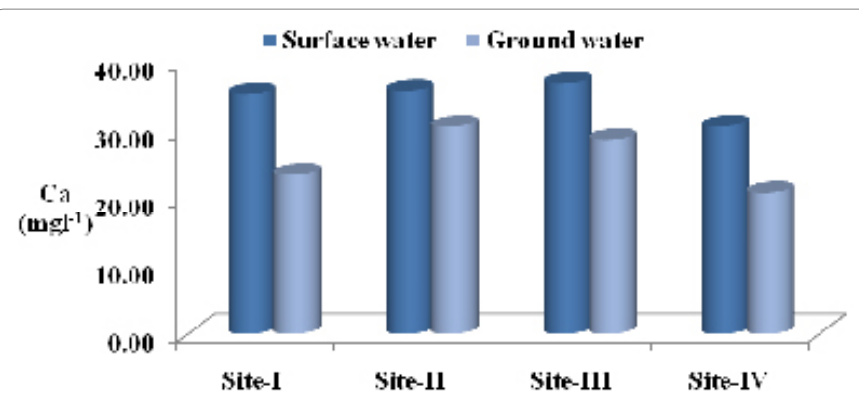

Figure 7: Variation of calcium (Ca) during study period.

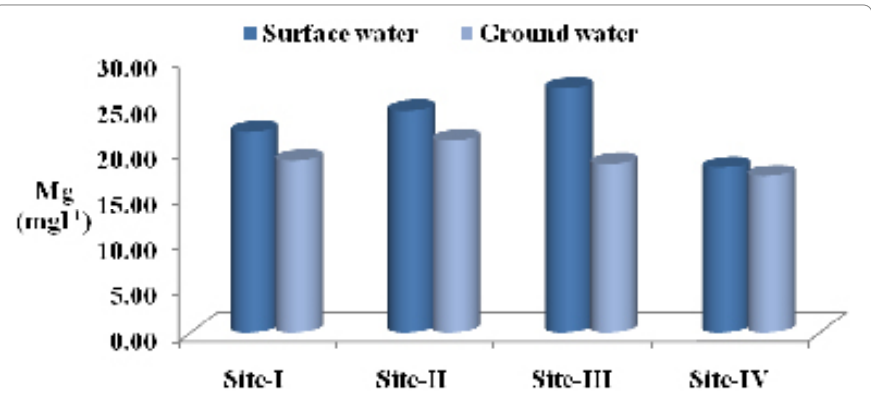

Figure 8: Variation of $\mathrm{Mg}$ during study period.

$\mathrm{Mg}$ was found in the range of 18.16 to 26.87 and 17.25 to 21.18 $\mathrm{mgl}^{-1}$ in surface and ground water, respectively which is low as compared to standard limit.

The ANOVA results exhibited that there was highly significant difference among the sites, at $0.05 \%$ level, both in surface and ground water.

It is common element and is essential for plant in the photosynthesis reaction and animal nutrition. The high level of $\mathrm{Mg}$ concentration in groundwater in coastal area indicates seawater contamination [25]. The acceptable limit of magnesium according to BIS (10500: 2012) is 30 $\mathrm{mgl}^{-1}$ and permissible limit is $100 \mathrm{mgl}^{-1}[31]$.

The result obtained aboved reveals that there is increase in contamination in the surface and ground water that could be accounted by urbanization, industralization, enthropogenic activity and various other factors [3-21].

\section{Conclusions}

Rapid industrialization and urban development results in deterioration of water quality. The average values of all physiochemical and alkali metals were found within the permissible limits of the WHO guideline for drinking water and also within Indian standard limits but some sites of surface and ground water were found to have even higher as compared to standard limit that may be due to excess use of chemicals and non judious or unplanned out flow of effluent. So, there is a need to establish sewage treatment plants in major human settlements so that untreated sewage couldn't contaminate the water bodies. Hence, regular and quantified monitoring of geochemical characteristics of the surface and ground water will be useful for sustainable water management.

\section{Acknowledgments}

We are highly thankful to the Director FRI. We appreciate the assistance provided by Mr. Rajendra Kumar in the lab work.

\section{References}

1. Ramkumar T, Venkatramanan S, Anithamary I, Ibrahim SM (2013) Evaluation of hydrogeochemical parameters and quality assessment of the groundwater in Kottur blocks, Tiruvarur district, Tamilnadu, India. Arabian Journal of Geosciences 6: 101-108.

2. Raven PH, Berg LR (2006) Environment. 5th edn, John Wiley \& Sons.

3. Dan'Azumi S, Bichi MH (2010) Industrial pollution and heavy metals profile of Challawa River in Kano, Nigeria. Journal of Applied Sciences in Environmental Sanitation 5: 23-29.

4. Chakrapani G (2002) Water and sediment geochemistry of major Kumaun Himalayan lakes, India. Environmental Geology 43: 99-107.

5. Semwal N, Akolkar P (2006) Water quality assessment of sacred Himalayan. Current Science, p: 91

6. Kumar A, Bahadur Y (2009) Physico-Chemical Studies on the Pollution 
Citation: Kumar R, Chauhan A, Rawat L (2017) Physico-chemical Analysis of Surface and Ground Water in Selected Sites of Dehradun, Uttarakhand, India. J Environ Anal Toxicol 6: 420. doi: 10.4172/2161-0525.1000420

Page 6 of 6

Potential of River Kosi at Rampur (India). World Journal of Agricultural Sciences 5: 1-4.

7. Kaushik A, Kansal A, Kumari S, Kaushik CP (2009) Heavy metal contamination of river Yamuna, Haryana, India: assessment by metal enrichment factor of the sediments. Journal of hazardous materials 164: 265-270.

8. Volesky B (1994) Advances in biosorption of metals: selection of biomass types. FEMS Microbiology Reviews 14: 291-302.

9. Griffith JA (2002) Geographic techniques and recent applications of remote sensing to landscape-water quality studies. Water, Air, and Soil Pollution 138: 181-197.

10. Carpenter SR, Caraco NF, Correll DL, Howarth RW, Sharpley AN, et al. (1998) Nonpoint pollution of surface waters with phosphorus and nitrogen. Ecological applications 8: 559-568

11. Vijith H, Satheesh R (2007) Geographical Information System based assessment of spatiotemporal characteristics of groundwater quality of upland sub-watersheds of Meenachil River, parts of Western Ghats, Kottayam District, Kerala, India. Environ Geol 53: 1-9.

12. Bhagwat IP (2008) Drought and Drinking water crisis in Bundelkhand, Water Aid India.

13. Basnyat P, Teeter LD, Flynn KM, Lockaby BG (1999) Relationships between landscape characteristics and nonpoint source pollution inputs to coastal estuaries. Environmental management 23: 539-549.

14. Jain SK, Agarwal PK, Singh VP (2007) Indus Basin. In: Hydrology and Water Resources of India 2007. Springer, Netherlands, pp: 473-511.

15. Kazi TG, Arain MB, Jamali MK, Jalbani N, Afridi HI, et al. (2009) Assessment of water quality of polluted lake using multivariate statistical techniques: A case study. Ecotoxicology and Environmental Safety 72: 301-309.

16. Giussani B, Monticelli D, Gambillara R, Pozzi A, Dossi C (2008) Three-way principal component analysis of chemical data from Lake Como watershed. Microchemical Journal 88: 160-166.

17. Subba N, Kumar P, Rawat L (2014) Floristic Diversity of Karwapani Wetland of Doon Valley, Uttarakhand, India.

18. Parashar NB, Kaushik P, Pandey S (2003) Physico-chemical and Microbiological
Studies of Ganga Canal at Haridwar during Kumbh period-1998. Him J Env Zool 17: 167-171.

19. Kumar A, Bisht BS, Talwar A, Chandel D (2010) Physico-chemical and microbial analysis of ground water from different regions of Doon valley. Int Jou Appl Env Sci 5: 433-440.

20. Abegaz SM (2005) Investigation of input and distribution of polluting elements in Tinishu Akaki River, Ethiopia, based on the determination by ICP-MS. PhD Thesis, Ghent University, Belgium, p: 221.

21. Fakayode SO (2005) Impact of industrial effluents on water quality of the receiving Alaro River in Ibadan, Nigeria. Ajeam-Ragee 10: 1-13.

22. Narayana J, Purushothama R, Kiran BR, Ravindrakumar KP, Puttah ET (2005) Investigation of drinking water quality of Basavanahole Tank with reference to physical chemical characteristics. Funda of limno, pp: 201-206.

23. Jain CK, Kumar S, Rao YR (2004) Trace element contamination in a coastal aquifer of Andhra Pradesh. Pollution Research 23: 13-23.

24. Jameel AA, Sirajudeen J (2006) Risk assessment of physico-chemical contaminants in groundwater of pettavaithalai area, tiruchirappalli, Tamilnadu, India. Environmental Monitoring and Assessment 123: 299-312.

25. Tripathi DK, Pandey G, Jain CK (2015) Physicochemical Analysis of Selected Springs water samples of Dehradun city, Uttarakhand, India. International Journal for Innovative Research in Science and Technology 2: 99-103.

26. WHO (1984) Guidelines for drinking water quality. Volume I Recommendations, World Health Organization, Geneva.

27. Jain CK, Bandyopadhyay A, Bhadra A (2010) Assessment of ground water quality for drinking purpose, District Nainital, Uttarakhand, India. Environmenta monitoring and assessment 166: 663-676.

28. ISI (1993) Indian standard specification for drinking water. New Delhi, ISI 10500.

29. WHO (1996) Guidelines for drinking water quality. Recommendation 1, Geneva: World Health Organization (WHO).

30. PSQCA (2002) Drinking water. Pakistan standards and quality control authority (PSQCA), Karachi, Pakistan.

31. BIS (1991) Indian standard drinking water specification. IS 10500. 